\title{
PERTANGGUNGJAWABAN GOJEK AKIBAT KEHILANGAN \\ BARANG PADA FITUR GO-SEND SEBAGAI LAYANAN YANG DITAWARKAN DALAM GOJEK INDONESIA*
}

\author{
Oleh: \\ Anak Agung Ayu Krisnanti Larasati** \\ Made Maharta Yasa, SH., MH ${ }^{* * *}$ \\ Program Kekhususan Hukum Bisnis, Fakultas Hukum Universitas \\ Udayana
}

\begin{abstract}
Abstrak
Pengiriman barang dengan menggunakan jasa ekspedisi pos merupakan sebuah hal yang konvensional pada era modern saat ini. Pengiriman jarak pendek saat ini lebih banyak digantikan oleh jasa pengiriman barang secara online, misalnya Gojek. Gojek Indonesia menawarkan item Go-send bagi masyarakat yang hendak melakukan pengiriman. Namun sejalan dengan itu, lemahnya hukum dan materi dalam pengaturan kebijakan Gojek mengakibatkan tidak terimplementasinya kepastian hukum. Tulisan ini disusun untuk dapat menjawab bagaimana pertanggungjawaban yang diberikan terhadap pengguna Jasa Gojek di Indonesia dan bagaimanakah bentuk ganti rugi yang diberikan oleh Gojek atas klaim kehilangan barang yang terjadi pada jasa Gosend yang ditawarkannya. Tulisan ini bertujuan untuk memberikan deskripsi terkait hak dari pengguna serta kewajiban yang harus dipenuhi oleh Gojek sendiri serta menjelaskan bentuk ganti rugi yang dilakukan oleh pihak gojek sebagai bentuk pertanggungjawaban atas komplain penggunaan jasa Go-Send. Metode yang digunakan adalah metode penelitian hukum normatif yang didukung dengan pendekatan perundang-undangan, pendekatan analisis dan konseptual, dan pendekatan kasus. Hasil akhir dari penyusunan jurnal ini adalah pertanggungjawaban yang diberikan kepada konsumen atas kehilangan barang pada jasa yang ditawarkannya dengan cara memberikan ganti rugi serta bentuk ganti rugi yang ditetapkan secara yurudis adalah ganti rugi berupa
\end{abstract}

\footnotetext{
*Aspek Pertanggungjawaban Gojek Akibat Kerusakan Barang Pada Fitur Go-Send Sebagai Layanan Yang Ditawarkan Dalam Gojek Indonesia merupakan makalah ilmiah di luar ringkasan skripsi.

${ }^{* *}$ Anak Agung Ayu Krisnanti Larasati adalah Mahasiswi Fakultas Hukum Universitas Udayana. Korespondensi: inalarasati88@gmail.com

${ }^{* * *}$ Made Maharta Yasa, SH.,MH adalah Dosen Fakultas Hukum Universitas Udayana. Korespondensi: mdmahartayasa@gmail.com
} 
sejumlah uang sebagai bentuk pertanggungjawaban nominal serta ganti rugi melalui saham ataupun barang serupa.

Kata Kunci : Cacat, Ganti-rugi, Gojek, Kelalaian, Kehilangan, Pengiriman.

\begin{abstract}
Shipping goods using postal expedition services is a conventional thing in the modern era. Short-distance shipping is currently being replaced more by online shipping services, such as Gojek. Gojek Indonesia offers Go-send items for people who want to send. But in line with that, the weakness of law and material in the regulation of Gojek policy resulted in the lack of implementation of legal certainty. This paper was prepared to be able to answer how accountability is given to users of Gojek Services in Indonesia and what forms of compensation provided by Gojek for claims of loss of goods that occur in Go-send services offered. This paper aims to provide a description of the rights of users and the obligations that must be fulfilled by Gojek itself and explain the forms of compensation made by the gojek as a form of accountability for complaints of the use of Go-Send services. The method used is a normative legal research method that is supported by a legal approach, an analytical and conceptual approach, and a case approach. The final result of the preparation of this journal is the responsibility given to consumers for the loss of goods in the services offered by providing compensation and forms of compensation that are judicially determined as compensation in the form of money as a form of nominal liability and compensation through shares or similar items .
\end{abstract}

Keywords : Defect, Compensation, Gojek, Negligence, Damage,

Shipment. 


\section{Pendahuluan}

\subsection{Latar Belakang}

Pengiriman barang merupakan hal yang sering dilakukan oleh sebagian besar masyarakat modern. Pengiriman barang dilakukan dengan memanfaatkan jasa pengiriman barang yang disediakan oleh setiap perusahaan jasa. ${ }^{1}$ Saat ini, pengiriman barang dan jasa cenderung dilakukan secara online dengan memanfaatkan fitur gosend pada Gojek Indonesia. ${ }^{2}$ Gojek merupakan sebuah perusahaan yang menyediakan jasa transportasi online yang dapat diakses secara online melalui aplikasi yang bisa diunduh pada google playstore atau apple appstore serta mampu diakses dalam halaman berbasis web dalam www.gojek.com. ${ }^{3}$ Gojek cenderung mengemukakan konsep inovatif untuk produknya. Sejalan dengan itu, jika mengacu pada teori pemasaran, Jonathan Sarwono dan Tutty Martadiredja mengemukakan bahwa keterlibatan pihak gojek sebagai merchant penting untuk menawarkan jasa yang dijualnya sehingga bisa mempertahankan statusnya di mata publik. ${ }^{4}$

Beberapa fitur yang populer ditawarkan dalam aplikasi gojek yakni Go-ride, Go-car, Go-Bluebird, Go-food, Go-Send, Go-Pulsa, dan beberapa jasa lain yang ditawarkan. Akan tetapi, penggunaan jasa Gojek juga tidak dapat sepenuhnya bebas dari tindakan kriminal. Penipuan, pembunuhan, perampasan, pencurian, pemerkosaan menjadi sebuah kesan yang mewarnai kesuksesan perkembangan gojek di tanah air. Misalnya, kasus pembunuhan yang dilakukan terhadap Ardhi Nuraswan seorang driver Go-Car oleh 4 (empat)

${ }^{1}$ Muhammad Fachurrozy dan Indra Rachmawati, 2017, "Analisis Kualitas Penilaian Pada Gojek Bandung”, Jurnal e-Proceeding Management, Program Studi Ilmu Managemen Bisnis Telekomunikasi dan Informatika Fakultas Ekonomi dan Bisnis Universitas Telkom, Volume 4, Nomor 3, h. 2506.

2 ibid, h. 2508.

3 ibid.

4 Jonathan Sarwono dan Tutty Martadiredja, 2008, "Teori E-Commerce, Kunci Sukses Berdagang di Internet”, Bandung: Gava Media, h. 9. 
orang tersangka yang dilakukan secara terencana dengan modus sebagai pengguna jasa Go-car. ${ }^{5}$

Gojek memilik beberapa aturan tersendiri yang terdapat pada menu term and policy. Akan tetapi, dari beberapa aturan yang dicantumkan dalam menu tersebut, gojek hanya memberi pertanggungjawaban ganti rugi sebesar 10 juta, jika barang melebihi dari harga 10 juta maka pihak gojek tidak mengganti sepenuhnya atas kehilangan tersebut. Seperti yang kita ketahui di aplikasi Gojek tidak terdapat kolom untuk mencantumkan nominal harga barang tersebut dan perkiraan harga barang tersebut, terdapat beberapa kasus pada fitur Go-Send yakni ketika barang yang diantarkan tidak sampai ke lokasi sang penerima seperti halnya pencurian Iphone 7+ yang dilakukan oleh seorang Driver Gojek bernama Fahriz Noor Rochman, pada 13 Juli 2017 Steven membeli sebuah Iphone $7+$ dari aplikasi Tokopedia, pada pukul 16.48 WIB driver gojek telah mengambil dan mengantar barang ke tempat tujuan, lalu pada pukul 16.53 WIB pemberitahuan aplikasi mengatakan barang tersebut sudah sampai tujuan tetapi pelanggan belum menerima barang tersebut dan driver gojek tidak bisa dihubungi kembali. ${ }^{6}$ Kasus tersebut terjadi pada tahun 2017, pada saat itu harga Iphone 7+ berkisar 10 juta keatas, lalu apakah Gojek hanya mengganti 10 Juta? tentu konsumen sangat dirugikan yang seharusnya konsumen menggunakan aplikasi tersebut ada rasa percaya dan tidak ada rasa resah akan kehilangan barang miliknya. Padahal, pertanggungjawaban merupakan sebuah unsur mutlak

5 Budi Rahmat, 2018, "Perencanaan Pembunuhan Sopir Gojek di Lakukan d Rumahi Kontrakan”, diakses dari http://www.tribunnews.com/regional/2018/ $02 / 12 /$ perencanaan-pembunuhan-sopir-gojek-dilakukan-di-rumah-kontrak an? page $=1$, pada hari Kamis, 16 Agustus 2018, pukul 21.14 WITA.

${ }^{6}$ Yulistyo Pramono, 2018, "Bukan Antarkan Pesanan, Driver Gojek Jurstru Bawa Lari iPhone 7+", diakses dari https: / / feed.merdeka.com/rumpi/bukanny aantarkan-pesanan-driver-ojek-online-bawa-lari-iphone-7-1707218.html, pada hari Jumat, 09 Januari 2019, pukul 11.30 WITA. 
yang seharusnya dipenuhi oleh sebuah perusahaan jika hendak melakukan sebuah usaha.

Dalam Pasal 7 huruf e Undang-Undang Nomor 8 Tahun 1999 tentang Perlindungan Konsumen (selanjutnya disebut UU Perlindungan Konsumen) telah ditetapkan bahwa seorang pelaku usaha wajib memberikan ganti rugi untuk penggunaan jasa yang diadakanya. Berkenaan dengan itu, lemahnya pertanggung jawaban yang terjadi menjadi sebuah kendala dalam menegakan hukum dan memberikan akses kepada masyarakat untuk mencapai keadilan. Dengan demikian, maka pembahasan yang berorientasi pada fitur Go-send pada gojek akan menarik untuk diungkapkan sebagai topik utama dalam penyusunan jurnal ini.

\subsection{Rumusan Masalah}

1.2.1 Bagaimana tanggung jawab Gojek terhadap kehilangan barang konsumen sebagai pengguna jasa Gojek?

1.2.2 Bagaimanakah bentuk ganti kerugian yang diberikan oleh Gojek atas klaim kehilangan barang yang terjadi pada jasa Gosend yang ditawarkannya?

\subsection{Tujuan Penulisan}

1.3.1 Untuk mengetahui tanggung jawab Gojek terhadap kehilangan barang konsumen sebagai pengguna jasa Gojek.

1.3.2 Untuk mengetahui bentuk ganti rugi yang diberikan oleh Gojek atas klaim kehilangan barang yang terjadi pada jasa Gosend yang ditawarkannya.

\section{Hasil dan Analisis}

\subsection{Metode Penulisan}

Metode yang digunakan dalam penyusunan tulisan ini adalah metode penelitian hukum normatif. Untuk mendukung kredibilitas 
dari informasi yang diberikan dalam penyusunan jurnal ini maka penulis memanfaatkan bentuk pendekatan perundang-undangan (the statue approach), pendekatan fakta (the fact approach) dan pendekatan analisis dan konseptual (analitical and conceptual approach). Sama halnya dengan penelitian kuantitatif yang dikemukakan oleh Burhan Bungin, penelitian ini menggunakan data sebagai salah satu alternatif pendukungnya. ${ }^{7}$ Penelitian ini merupakan penelitian monodisipliner dengan ruang lingkup ilmu hukum. ${ }^{8}$ Bahan hukum yang digunakan mencangkup bahan hukum primer berupa peraturan perundang-undangan, bahan hukum sekunder mencangkup literatur dan bahan bacaan lain serta bahan hukum tersier meliputi data pendukung berupa hasil survei dan lain-lain untuk meningkatkan kualitas materi muatan jurnal ini. ${ }^{9}$

\subsection{Pertanggungjawaban Gojek terhadap pengguna jasanya}

Aktifitas pengiriman barang merupakan sebuah perwujudan dari konsep kesepakatan yang sejatinya diatur secara khusus dalam Pasal 1320 Kitab Undang-Undang Hukum Perdata (untuk selanjutnya disebut KUHPerdata) yang merupakan sebuah unsur wajib dalam sebuah perjanjian. ${ }^{10} \mathrm{Hal}$ ini turut diterapkan oleh pihak perusahaan Gojek melalui fitur Go-send sebagai bentuk adanya kesepakatan, maka pihak Gojek akan memberikan sebuah resi pengiriman barang lengkap bersama alamat tujuan apabila pengirim telah melakukan applying pada aplikasi Gojek tersebut.

7 Burhan Bungin, 2007, "Penelitian Kualitatif, Komunikasi, Ekonomi, Kebijakan Publik dan Ilmu Sosial Lainnya”, Surabaya: Kencana, h. 67.

8Dyah Ochtorina Susanti, 2013, "Penelitian Hukum. Legal Research", Jember: Sinar Grafika, h. 21

9 Burhan Bungin Op.cit, h. 7.

10 Umar Said Sugiarto, 2012, "Pengantar Hukum Indonesia", Malang: Sinar Grafika h. 169. 
Untuk itu, maka pihak gojek yang akan bertanggungjawab pasca dilakukannya order barang melalui fitur Go-send.

Aturan penggunaan aplikasi terdapat pada menu term and policy. Dari beberapa aturan tersebut, sejatinya gojek mencantumkan klausul pertanggungjawaban atas kehilangan barang yang terbatas, sehingga mencerminkan adanya pengaturan yang lemah pada tindakan pertanggungjawaban. Padahal, pertanggung jawaban merupakan sebuah unsur mutlak yang seharusnya dipenuhi oleh sebuah perusahaan jika hendak melakukan sebuah usaha. ${ }^{11}$ Di dalam peraturan perundangundangan juga sudah di atur mengenai bagaimana tanggung jawab dari para pelaku usaha dalam menjalankan usahanya. Jika dikaitkan dengan UU Perlindungan Konsumen Pasal 18 ayat (1), ayat (2) dan ayat (3) yang menyatakan batal demi hukum setiap klausula baku yang telah ditetapkan oleh pelaku usaha pada dokumen yang memuat ketentuan yang dilarang dalam Pasal 18 ayat (1) UU Perindungan Konsumen. Ini juga berarti suatu klausula baku dalam transaksi secara langsung diluar lingkup dunia maya yang memuat ketentuan mengenai klausula baku yang dilarang dalam Pasal 18 ayat (1) Undang-undang Perlindungan Konsumen dianggap tidak pernah ada dan mengikat para pihak. ${ }^{12}$

Akan tetapi, jika mengkritisi persoalan tersebut dengan menitikberatkan kebijakan gojek pada Ketentuan Penggunaan poin 1 tentang Hal-Hal Umum angka 5 yang menyatakan "Untuk

11 Dhevy Nhayasari Sastradinata, 2016, "Tanggungjawab Persuahaan Penyedia Jasa Akibat Perbuatan Melawan Hukum Yang Dilakukan Oleh Pekerja Outsorching", Program Studi Ilmu Hukum, Fakultas Hukum Universitas Islam Lamongan, Jurnal Independent, Volume 6, Nomor 1, h. 53.

12 Ni Putu Ria Dewi Marheni Mahasiswa, 2014, "Perlindungan Hukum Bagi Konsumen Berkaitan Dengan Pencantuman Disclaimer Oleh 4 Pelaku Usaha Dalam Situs Internet (website)", Jurnal Kertha Patrika, Program Studi Ilmu Hukum, Fakultas Hukum Universitas Udayana, Volume 3, Nomor 1, h. 14. 
menghindari keragu-raguan, kami adalah perusahaan teknologi, bukan perusahaan transportasi atau kurir dan kami tidak memberikan layanan transportasi atau kurir. Kami tidak mempekerjakan Penyedia Layanan dan kami tidak bertanggung jawab atas setiap tindakan dan/atau kelalaian Penyedia Layanan. Aplikasi ini hanya merupakan sarana untuk memudahkan pencarian atas Layanan. Adalah tergantung pada Penyedia Layanan untuk menawarkan Layanan kepada Anda dan tergantung pada Anda apakah Anda akan menerima tawaran Layanan dari Penyedia Layanan". ${ }^{13} \mathrm{Hal}$ ini menunjukan bahwa pihak Gojek telah sematamata melepaskan diri dari tanggungjawabnya sebagai pelaku usaha. Pasal 19 UU Perlindungan Konsumen telah menentukan bahwa pelaku usaha bertanggungjawab akan kehilangan maupun kerusakan dan seharusnya memberikan restitusi atau ganti rugi atas jasa yang dihasilkannya. Mengenai hal ini Ahmad Miru dan Sutarman Yodo berpandangan bahwa lingkup pertanggungjawaban pada Pasal 19 mencangkup cacat fisik ataupun kerugian materi akibat tindakan tertentu dari seorang pelaku usaha. ${ }^{14}$ Sehubung dengan itu, eksistensi dari kebijakan Go-send yang notabenenya melakukan aktifitas pos sebab telah memenuhi unsur pelayanan, transaksi, interkoneksi serta adanya sebuah kiriman jika mengacu pada Undang-Undang Nomor 38 Tahun 2009 tentang Pos. Namun yang berbeda adalah keterbatasan jangkauan dari pengiriman barang oleh Gojek belum sepenuhnya menampilkan adanya interkoneksi yang luas sama halnya dengan Pos Indonesia. Pada Pasal 31 ayat (2) Undang-Undang Nomor 38 Tahun 2009 tentang Pos telah ditentukan bahwa pihak pemberi layanan pos wajib

13. Go-Jek, 2018, "Ketentuan Penggunaan", diakses dari https://www.gojek.com/terms-and-condition/, pada tanggal 21 Agustus 2018, pukul 23.22 WITA.

14 Ahmadi Miru dan Sutarman Yodo, 2017, "Hukum Perlindungan Konsumen", Jakarta: Rajawali Pers, h. 131. 
memberikan ganti rugi atas kerusakan barang yang diklaim oleh pengguna jasanya. Pasal 4 UU Perlindungan Konsumen telah menetapkan salah satu hak dari konsumen yakni untuk mendapatkan jaminan atas keamanan dan keselamatan barangnya agar terhindar dari kerugian fisik maupun psikis. ${ }^{15}$

Dalam konteks perkembangan perusahaan dewasa ini, sudah sewajarnya perusahaan tidak hanya berfokus pada tanggung jawab untuk mengejar profit demi kelangsungan usaha, melainkan juga bertanggung jawab terhadap aspek sosial masyarakat. ${ }^{16}$

\subsection{Bentuk Ganti Kerugian Yang Diberikan Oleh Gojek Atas Klaim Kehilangan Barang Yang Terjadi Pada Jasa Go-Send Yang Ditawarkannya.}

Ganti rugi merupakan sebuah tindakan lain yang ditawarkan oleh seorang pelaku usaha atas klaim kehilangan maupun kerusakan barang yang terjadi pada barang ataupun jasa yang ditawarkannya. ${ }^{17}$ Bentuk ganti rugi juga dapat dibenarkan sebagai sebuah tindakan untuk mempertahankan kredibilitas dari perusahaan penyedia jasa yang bertindak sebagai seorang pelaku usaha. Rocky Marbun dkk menjelaskan bahwa ganti rugi ditujukan untuk memenuhi sejumlah uang. ${ }^{18}$ Konsep ganti rugi ini tampaknya merupakan sebuah aliran berpikir yang menekankan prinsip

15 Ahmadi Miru dan Sutarman Yodo, Op.cit, h. 41.

${ }^{16}$ Ida Ayu Sukihana dan I Gede Agus Kurniawan, 2017, "Pelaksanaan Pasal 74 Undang Undang No. 40 Tahun 2007 Tentang Perseroan Terbatas Berkaitan Dengan Tanggung Jawab Sosial Perusahaan Di Kabupaten Tabanan", Jurnal Kertha Patrika, Program Studi Ilmu Hukum Fakultas Hukum Universitas Udayana, Volume 39, Nomor 3, h. 197.

17 A.A.A Nadia Andina Putri dan Nyoman Mas Aryani, 2016, "Perlindungan Hukum Terhadap konsumen Pengguna Jasa Pengiriman Barang Dalam Hal Keterlambatan Sampainya Barang”, Jurnal Kertasemaya, Program Studi Ilmu Hukum Fakultas Hukum Universitas Udayana, Volume 4, Nomor 3, h. 3.

18 Rocky Marbun, et.al, 2012, "Kamus Hukum Lengkap, Mencangkup Istilah Hukum dan Perundang-Undangan Terbaru”, Jakarta: Visi Media, h. 109. 
ekonomi sebagai orientasi utama. Akan tetapi, sejalan dengan perkembangan zaman maka prinsip pemikiran ekonomis yang memposisikan uang pada posisi yang vital mengalami pergeseran yang kemudian digantikan dengan jasa, barang ataupun kemudahan-kemudahan tertentu. ${ }^{19}$ Dengan demikian, maka hukum yang mengikuti dinamika masyarakat juga memiliki pengaturan secara khusus tentang ganti rugi atas klaim kehilangan barang yang dilakukan oleh seorang konsumen. Ganti rugi yang dimaksudkan dalam Pasal 19 UU Perlindungan Konsumen yakni berupa memberikan sejumlah uang ataupun mengganti dengan barang sejenis lainnya. Disamping itu, ganti rugi juga dapat diberikan dengan memberikan santunan yang layak bagi seorang konsumen yang melakukan klaim ganti rugi. Hal tersebut patutnya dilakukan dengan itikad baik dengan menempatkan masing-masing pihak pada posisi yang sama tanpa mendominankan salah satu pihak.

Menarik untuk dicermati bahwa terdapat kebijakan dari Gojek yang hanya memberikan uang ganti rugi maksimal hanya 10 Juta rupiah untuk kehilangan yang diakibatkan oleh Gojek, bagaimana jika barang tersebut diatas 10 Juta, apakah akan diganti kerugiannya hanya 10 Juta? sudah tentu pihak pengguna aplikasi dirugikan jika tidak dikembalikan seluruhnya sesuai harga barang. Seharusnya pihak Gojek memberikan ganti rugi seluruhnya dikarenakan Gojek memberikan fasilitas transportasi pengiriman barang dan kesalahan dari pihak Gojek yang seharusnya sudah diperhitungkan sebelum melaksanakan aktivitas jasa transportasi online.

Dengan demikian, maka dapat disimpulkan bahwa kehilangan barang tidak sampai di tempat atau rusak saat diangkut oleh driver

${ }^{19}$ Dhevy Nhayasari Sastradinata, Op.cit, h. 54 
adalah dengan memberikan ganti rugi berupa uang seluruhnya sesuai dengan harga barang ataupun tindakan lain yang dilakukan melalui itikad baik antara kedua belah pihak sehingga bisa terlaksana unsur kekeluargaan yang diharapkan dari aspek perdata serta memberikan akses keadilan dan kepastian hukum kepada semua pihak.

\section{Penutup}

\subsection{Kesimpulan}

Berdasarkan pembahasan diatas maka dapat disimpulkan bahwa :

1. Pertanggungjawaban yang diberikan terhadap pengguna jasa Go-send yang merupakan salah satu item yang ditawarkan oleh Gojek adalah dengan memberikan ganti rugi yang layak atas kesalahan ataupun kegagalan dalam menggunakan jasa tersebut. Mengacu pada Pasal 31 ayat (2) Undang-Undang Nomor 38 Tahun 2009 tentang Pos sejatinya telah tegas bahwa Go-send merupakan sebuah jasa serupa dengan Pos harus memberikan layanan ganti rugi terhadap pengguna jasa tersebut jika pada kenyataannya terbukti bahwa telah terjadi sebuah pencurian ataupun kelalaian yang mengakibatkan cacatnya barang yang dikirim. Pada Pasal 4 UU Perlindungan Konsumen juga turut menegaskan ganti rugi yang wajib diberikan kepada konsumen dari pelaku usaha.

2. Bentuk ganti rugi yang harus diberikan kepada konsumen yang mengalami kerugian atas penggunaan jasa Go-send dengan mengacu pada Pasal 19 UU Perlindungan Konsumen maka bentuk ganti rugi dapat berupa memberikan sejumlah uang seluruhnya sesuai dengan 
harga barang sebagai pertanggungjawaban nominal; ganti rugi dengan memberikan saham ataupun barang sejenis lainnya.

\subsection{Saran}

1. Sebagai bentuk perlindungan terhadap konsumen maka pemerintah perlu untuk mengidentifikasi kembali kebijakan gojek yang mencantumkan klasula eksonerasi untuk melepas tuntutan hukum dalam melaksanakan prestasinya.

2. Bentuk ganti rugi yang layak cenderung disalahartikan oleh pihak pelaku usaha sebab kecenderungan untuk melakukan monopoli keuntungan. Dengan demikian, maka pelaku usaha harus kembali membenahi peraturannya sehingga memiliki pola pikir yang searah dengan amanat undang-undang. 


\section{DAFTAR PUSTAKA}

\section{Buku}

Bungin, Burhan. 2007. "Penelitian Kualitatif, Komunikasi, Ekonomi, Kebijakan Publik dan Ilmu Sosial Lainnya”. Surabaya: Kencana.

Marbun, Rocky. et.al. 2012. "Kamus Hukum Lengkap, Mencangkup Istilah Hukum dan Perundang-Undangan Terbaru”. Jakarta: Visi Media.

Miru, Ahmadi dan Sutarman Yodo. 2017. "Hukum Perlindungan Konsumen”. Jakarta: Rajawali Pers.

Sarwono, Jonathan dan Tutty Martadiredja. 2008. "Teori ECommerce, Kunci Sukses Berdagang di Internet”. Bandung: Gava Media.

Sugiarto, Umar Said. 2012. "Pengantar Hukum Indonesia”. Malang: Sinar Grafika.

Susanti, Dyah Ochtorina. 2013. "Penelitian Hukum. Legal Research", Jember: Sinar Grafika.

\section{Jurnal}

Fachurrozy, Muhammad dan Indra Rachmawati. 2017. "Analisis Kualitas Penilaian Pada Gojek Bandung”. Jurnal e-Proceeding Management. Program Studi Ilmu Managemen Bisnis Telekomunikasi dan Informatika Fakultas Ekonomi dan Bisnis Universitas Telkom. Volume 4. Nomor 3.

Lumba, Hermawan. 2014. "Pertanggungjawaban Perusahaan Ekspeditur Kepada Konsumen Berdasarkan UU 8 Tahun 1999 tentang Perlindungan Konsumen”. Jurnal Ilmu Hukum. Program Studi Ilmu Hukum Fakultas Hukum Untag Surabaya. (tanpa volume). (tanpa tahun).

Marheni, Ni Putu Ria Dewi. 2014. "Perlindungan Hukum Bagi Konsumen Berkaitan Dengan Pencantuman Disclaimer Oleh Pelaku Usaha Dalam Situs Internet (website)". Jurnal Kertha Patrika. Program Studi Ilmu Hukum Fakultas Hukum Universitas Udayana. Volume 3. Nomor 1.

Putra, I Gusti Ngurah Krisna Aribhuana, Ida Bagus Putra Atmadja, dan Ni Putu Purwanti. 2018. "Tanggung Jawab PT Pos 
Indonesia Dalam Layanan Jasa Pengiriman Barang Yang Mengalami Keterlambatan (Studi Pada PT Pos Indonesia Cabang Ubud)". Jurnal Kertha Semaya. Program Studi Ilmu Hukum Fakultas Hukum Universitas Udayana. Volume 6. Nomor 5.

Putri, A.A.A Nadia Andina dan Nyoman Mas Aryani. 2016. "Perlindungan Hukum Terhadap konsumen Pengguna Jasa Pengiriman Barang Dalam Hal Keterlambatan Sampainya Barang". Jurnal Kertha Semaya. Program Studi Ilmu Hukum Fakultas Hukum Universitas Udayana. Volume 4. Nomor 3.

Sastradinata, Dhevy Nhayasari. 2016. "Tanggungjawab Persuahaan Penyedia Jasa Akibat Perbuatan Melawan Hukum Yang Dilakukan Oleh Pekerja Outsorching". Program Studi Ilmu Hukum. Fakultas Hukum Universitas Islam Lamongan. Jurnal Independent. Volume 6. Nomor 1.

Sukihana, Ida Ayu dan I Gede Agus Kurniawan. 2017. "Pelaksanaan Pasal 74 Undang-Undang No. 40 Tahun 2007 Tentang Perseroan Terbatas Berkaitan Dengan Tanggung Jawab Sosial Perusahaan Di Kabupaten Tabanan. Jurnal Kertha Patrika". Program Studi Ilmu Hukum Fakultas Hukum Universitas Udayana. Volume 39. Nomor 3.

\section{Bahan Internet}

Go-Jek. 2018. "Ketentuan Penggunaan". Diakses dari https://www.go-jek.com/terms-and-condition/. Pada tanggal 21 Agustus 2018. Pukul 23.22 WITA.

R, Mei Amelia. 2018. "Detik-Detik Pembunuhan Dini Oleh Seorang Driver Gojek Online Terekam CCTV". Diakses dari https://news.detik.com/ berita/d-36 54402/detik-detikpembunuhan-dini-oleh-driver-ojek-online-terekam-cctv. Pada hari Kamis, 16 Agustus 2018. Pukul 21.28 WITA.

Pramono,Yulistyo. 2018. "Bukan Antarkan Pesanan, Driver Gojek Jurstru Bawa Lari iPhone 7+". Diakses dari https://feed.merdeka.co m/rumpi/bukan ny a-antarkanpesanan-driver-ojek-online-bawa-lari-iphone-7-1707218.html. Pada hari Jumat, 17 Agustus 2018. Pukul 16.31 WITA.

Rahmat, Budi. 2018. "Perencanaan Pembunuhan Sopir Gojek di Lakukan d Rumahi Kontrakan". Diakses dari 
http://www.tribunnews.co

$\mathrm{m} / \mathrm{regional} / 2018 /$

02/12/perencanaan-pembunuhan-sopir-gojek-dilakukan-dirumah-kontrak an? page $=1$. Pada hari Kamis, 16 Agustus 2018. Pukul 21.14 WITA.

\section{Bahan Hukum}

Undang-Undang Dasar Tahun 1945

Kitab Undang-Undang Hukum Perdata

Undang-Undang Nomor 8 Tahun 1999 tentang Perlindungan Konsumen, diundangkan di Jakarta pada tanggal 20 April 1999 dalam Lembaran Negara Republik Indonesia Nomor 42, Tambahan Lembaran Negara Republik Indonesia Nomor 3821.

Undang-Undang Nomor 38 Tahun 2009 tentang Pos, diundangkan di Jakarta pada tanggal 14 Oktober 2009, dalam Lembaran Negara Republik Indonesia Tahun 2009 Nomor 146, Tambahan Lembaran Negara Republik Indonesia Nomor 5065. 